\title{
Impregnation of nanoparticle scaffolds for syngas-fed solid oxide fuel cell anodes
}

\author{
P. Boldrin ${ }^{\mathrm{a}}$, E. Ruiz-Trejo ${ }^{\mathrm{a}}$, C. Tighe ${ }^{\mathrm{b}}$, K. C. Chang ${ }^{\mathrm{c}}$, J. Darr ${ }^{\mathrm{d}}$ and N. P. Brandon ${ }^{\mathrm{a}}$ \\ ${ }^{a}$ Department of Earth Science and Engineering, Imperial College London, London, SW7 \\ 2AZ, UK \\ ${ }^{\mathrm{b}}$ Department of Chemical Engineering, Imperial College London, London, SW7 2AZ, \\ UK \\ ${ }^{c}$ Materials Science Division, Argonne National Laboratory, Argonne, IL 60439, USA \\ ${ }^{\mathrm{d}}$ Department of Chemistry, University College London, London, WC1H 0AJ
}

\begin{abstract}
A strategy for fabrication of solid oxide fuel cell anodes with improved porosity and lower sintering temperatures by impregnation of nanoparticle-containing porous scaffolds of ceriagadolinia (CGO) has been developed. The CGO scaffolds are fabricated using a screen-printed ink containing nanoparticles and commercial particles of $\mathrm{CGO}$ and polymeric pore formers. Scanning electron microscopy and in situ ultra-small angle X-ray scattering show that incorporation of nanoparticles increases the porosity by allowing a reduction in sintering temperature. Electrochemical characterisation of symmetrical cells shows that the cells sintered at $1000{ }^{\circ} \mathrm{C}$ possess similar electrode polarisation compared to those sintered at $1300{ }^{\circ} \mathrm{C}$. Button cell testing showed that reducing the sintering temperature produced cells which perform better at $700{ }^{\circ} \mathrm{C}$ and below in hydrogen, and performed better at all temperatures using syngas. This approach has the potential to allow the use of a wider range of nanomaterials, giving a finer control over microstructure.
\end{abstract}

\section{Introduction}

Incorporation of nanomaterials into devices such as solid oxide fuel cell (SOFC) electrodes has the potential to improve surface areas, lower heat-treatment temperatures, allow finer control over microstructure and could give access to new functionality. However, the use of inorganic nanomaterials has been hampered by the difficulties of fabricating devices using traditional processing techniques such as screen printing or tapecasting(1). In a typical ceramic fabrication process, an ink is formulated by suspending the ceramic particles in a liquid containing dispersants and binders(2). When dried, this ink can form a monolith if tape cast or a film on a support if screen printed. The difficulty with using nanomaterials has been to maintain a workable viscosity for the ink while increasing the solid loading to levels which are linked to important properties in the final product such as increased density, better particle interconnectedness, and potentially increased adhesion to the substrate and uniformity(3-5).

Typically, SOFC anodes are three-dimensionally-percolating mixtures of an electronconducting metal and an oxide-conducting ceramic, with electrochemical reactions taking place at the interface between metal, ceramic and gas, known as the triple phase boundary (TPB). Maximising the TPB length should improve the performance of the electrode. 
Good adhesion to the current collector and electrolyte are also required to reduce ohmic losses. Normally an ink of nickel oxide and doped ceria or zirconia will be used, and this will need to be heat-treated at $1300{ }^{\circ} \mathrm{C}$ or higher to produce well-adhered and physicallystable electrodes.

A fabrication method which may help improve triple phase boundary length is impregnation (also known as infiltration) of porous scaffolds, where the ceramic component of the anode is printed as an ink, forming a porous scaffold after heattreatment. The metal component is added afterwards by impregnation of metal nitrate solution into the scaffold(6-7). Hitherto, this method has only used conventional (>1 $\mu \mathrm{m})$ sized particles for the scaffold. The use of nanomaterials may be able to produce finer microstructures, increase the TPB length further and allow use of new materials.

In this study we report on the fabrication of CGO scaffolds using a mixture of nano and larger commercial particles, with pore formers. We demonstrate that the incorporation of the nanoparticles results in physically-stable electrodes after sintering at only $1000{ }^{\circ} \mathrm{C}$, giving electrodes with significantly higher porosity and producing cells with superior low temperature performance compared to cells produced using a standard heat-treatment temperature of $1300{ }^{\circ} \mathrm{C}$ in hydrogen and at all temperatures in syngas fuel.

\section{Experimental}

Inks were formulated from a mixture of commercial gadolinia-doped ceria $\left(\mathrm{Ce}_{0.9} \mathrm{Gd}_{0.1} \mathrm{O}_{1.97}\right.$, CGO, particle size $\left.=0.5 \mu \mathrm{m}\right)$ from Praxair, nanoparticle CGO $\left(\mathrm{Ce}_{0.9} \mathrm{Gd}_{0.1} \mathrm{O}_{1.97}\right.$, particle size $=5 \mathrm{~nm}$ from TEM $)$ produced by continuous hydrothermal flow synthesis (CHFS), polymer microbeads (6 $\mu \mathrm{m}$, Microbeads AS, Spheromers CA6), terpineol as a solvent, Hypermer KD15 as a dispersant and an ethylcellulose binder (Hercules EC N-7). The CGO nanopowders were produced by continuous hydrothermal flow synthesis using a pilot plant at University College London as described elsewhere(8). CHFS has previously been used to make samaria-doped ceria(9), ceria-zirconia solid solutions(10-11), an entire phase diagram of 66 ceria-zirconia-yttria samples(12) and a range of other metal oxides(13-14) and phosphates(15) with typically sub $50 \mathrm{~nm}$ diameter. In CHFS, an aqueous mixture of cerium ammonium nitrate and gadolinium nitrate solution was continuously mixed with a stream of superheated water at $450{ }^{\circ} \mathrm{C}$ and 22.1 $\mathrm{MPa}$ in a patented confined jet mixer(16). Particles were then cooled (via a pipe cooler) and then collected as an aqueous slurry at the exit of the back-pressure regulator.

For preparation of scaffolds, the solvent $(0.653 \mathrm{~g})$, dispersant $(0.265 \mathrm{~g})$ and binder $(0.040 \mathrm{~g})$ were mixed together until the binder had fully dissolved. Next, with stirring in an ultrasonic bath, each solid component was added sequentially in two or three aliquots, starting with the dried CGO nanoparticles $(0.751 \mathrm{~g})$, followed by the commercial CGO $(1.047 \mathrm{~g})$, and finally the polymer microbeads $(0.153 \mathrm{~g})$. The ultrasonication and stirring is effective in suspending the nanoparticles. This gave an ink with ca. 26 vol\% solids content, which was an acceptable level for a screen printing ink(3).

The inks were screen printed onto $200 \mu \mathrm{m}$ thick yttria-stabilised zirconia (YSZ) electrolytes. In the case of fuel cells, the procedure differed slightly between cells with different sintering temperatures for the anode. In the cells with scaffolds sintered at $1300{ }^{\circ} \mathrm{C}$, one side was printed with the scaffold ink, while the other was printed with a 
thin layer of a CGO ink (this is to prevent reactions between the cathode material and the YSZ electrolyte). The printed pellets were then heat-treated at $1300{ }^{\circ} \mathrm{C}$ for one hour, with a $1{ }^{\circ} \mathrm{C} / \mathrm{min}$ ramp rate during heating and cooling. The LSCF-CGO cathode (ink purchased from Fuel Cell Materials, Columbus, OH, USA) was then screen-printed, and the cell heat-treated at $1100{ }^{\circ} \mathrm{C}$ for three hours with a $5{ }^{\circ} \mathrm{C} / \mathrm{min}$ ramp rate during heating and cooling. The process for the cells with scaffolds heat-treated at $1000{ }^{\circ} \mathrm{C}$ was identical except the order of printing and sintering was a protective CGO layer first, followed by cathode and finally by the CGO scaffold. Cells with one, two or three layers of CGO scaffold were produced. The scaffold was dried in an oven at $\sim 80{ }^{\circ} \mathrm{C}$ in between each printing cycle.

Next, the CGO scaffolds were impregnated with a nickel salt. The impregnation solution was prepared from $0.125 \mathrm{~g}$ of nickel nitrate hexahydrate in $200 \mu \mathrm{L}$ of absolute ethanol. The solution was dropped onto the scaffold using a $1-20 \mu \mathrm{L}$ pipette, with the volumes used determined empirically by visually observing whether the drop spread beyond the edge of the scaffold. If it did, then the volume of the following impregnation was reduced. The first volume used was determined by dropping pure ethanol onto the scaffold. In between each impregnation, the pellets were placed into a furnace directly at $500{ }^{\circ} \mathrm{C}$ for 5 mins. This cycle was then repeated ten times. After the final impregnation, the pellets were placed into this furnace, and the temperature was increased to $800{ }^{\circ} \mathrm{C}$ at $5{ }^{\circ} \mathrm{C} / \mathrm{min}$ and held for eight hours before cooling at $5{ }^{\circ} \mathrm{C} / \mathrm{min}$. The $\mathrm{NiO}$ loading was determined by weighing.

Four symmetrical cells were produced: a single layer cell heat-treated at $1300{ }^{\circ} \mathrm{C}$; a single layer cell heat-treated at $1000{ }^{\circ} \mathrm{C}$; a double layer cell heat-treated at $1000{ }^{\circ} \mathrm{C}$ and a triple layer cell heat-treated at $1000{ }^{\circ} \mathrm{C}$. In addition, four button cells for fuel cell testing were produced from single and double layer CGO scaffolds heat-treated at $1000{ }^{\circ} \mathrm{C}$, and the same heat-treated at $1300{ }^{\circ} \mathrm{C}$.

The scaffolds were studied by Ultra Small Angle X-ray Scattering (USAXS) to obtain information about the pore structure, while the in situ measurements allowed us to monitor the development of the microstructure with temperature(17). For the USAXS measurements, single layered samples were printed onto MgO substrates (used instead of YSZ as it is less absorbing of X-rays) for analysis by USAXS. The USAXS data were taken at sector 15, Advanced Photon Source, Argonne National Laboratory. Briefly, small angle scattering intensities around the direct beam was measured using channel cut Si crystal monochrometers in a Bonse-Hart configuration. The x-ray energy was 16.8 $\mathrm{keV}$ and the beam size was $1.5 \times 0.4 \mathrm{~mm}$. The sample was mounted in a LinkAm heater for the in situ USAXS measurements. The USAXS intensity is plotted as a function of the scattering vector $q=4 \sin (\theta) / \lambda$ where $\lambda$ is the $x$-ray wavelength and $\theta$ is the scattering angle. The USAXS spectra can be viewed as the autocorrelation of the electron density fluctuations inside the sample, resulting from contrast between the pores and the powders. The USAXS is normally plotted in a log-log plot, and at low q Guinier approximation is valid so the USAXS intensity shows an inflection proportional to - $\exp \left(\mathrm{q}^{2} \mathrm{R}_{\mathrm{g}}{ }^{2 / 3}\right)$ where $\mathrm{R}_{\mathrm{g}}$ is the radius of gyration. At higher q values, the USAXS intensity follows a power law slope with an exponent of -3 , as expected from Porod's law from slit-smeared USAXS. Our USAXS could not resolve the Guinier inflection from the large pores made by polymer microbeads, so we used a combination of a powder law slope and a log-normal 
size distribution of spherical pores to model the USAXS intensity for non-linear least squares fitting.

Electrochemical measurements were carried out with an Autolab PGSTAT. Symmetrical cell tests were carried out under humidified hydrogen in nitrogen, while fuel cell tests were carried out under humidified hydrogen in nitrogen and humidified syngas in nitrogen $\left(15 \% \mathrm{H}_{2}, 25 \% \mathrm{CO}, 60 \% \mathrm{~N}_{2}\right)$. For the syngas tests the cells were put under load in $50 \% \mathrm{H}_{2}$ in $\mathrm{N}_{2}$ before switching to syngas and carrying out the measurements. This avoids the carbon deposition caused by direct exposure to syngas at OCV. In all cases the same procedure for reducing the anode was employed; the cells were heated under dry nitrogen to $765{ }^{\circ} \mathrm{C}$ at $5{ }^{\circ} \mathrm{C} \mathrm{min}{ }^{-1}$ before switching to humidified $10 \%$ hydrogen in nitrogen for one hour before cooling to the operating temperature. In all cases in this report, the humidification was carried out at $20^{\circ} \mathrm{C}$, giving a humidity of $2.3 \%$, while the gas compositions given refer to the gas compositions prior to humidification.

\section{Results and discussion}

Scaffolds heat-treated at both 1000 and $1300{ }^{\circ} \mathrm{C}$ were not removed by placing and removing Sellotape from the scaffold, indicating that they were physically stable and adhered to the electrolyte. Scaffolds produced from CGO are not normally stable after heat-treatment at $1000{ }^{\circ} \mathrm{C}$, a fact which was confirmed by producing a similar ink but with the nanoparticle portion replaced with extra commercial CGO. Scaffolds produced from this ink and heat-treated at $1000{ }^{\circ} \mathrm{C}$ were not stable and could be removed even by the slight breeze caused by opening the furnace after heat-treatment. This indicates that the nanoparticle CGO is acting as a sintering aid, binding together the commercial CGO particles and adhering the scaffold to the electrolyte.

SEM imaging of the scaffolds (figure 1) showed differences between the structures, with the finer microstructure of the scaffold heat-treated at $1000{ }^{\circ} \mathrm{C}$ obvious. The microstructure of the scaffold heat-treated at $1300{ }^{\circ} \mathrm{C}$ appeared typical of ceria heattreated at such a temperature, with no obvious indication of the influence of the nanoparticles. Both scaffolds showed pores of ca. $6 \mu \mathrm{m}$ caused by the removal of the pore formers, and both showed a thickness of ca. $10 \mu \mathrm{m}$.

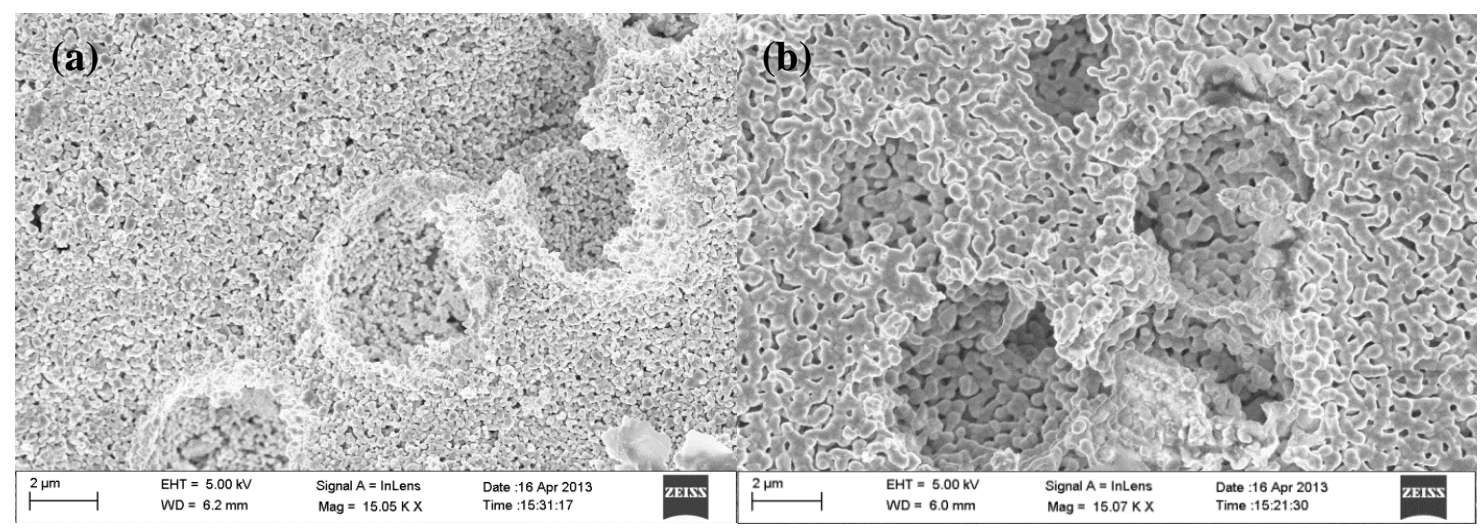

Figure 1. Porous CGO scaffolds heat-treated at $1000{ }^{\circ} \mathrm{C}$ (a) and $1300{ }^{\circ} \mathrm{C} \mathrm{(b)}$ at $15 \mathrm{k}$ magnification 
In situ USAXS carried out during the heat-treatment of a scaffold (figure 2) shows the development of the pore structure with temperature. At lower temperatures there is a bimodal pore size distribution. The smaller pores begin to increase in size and decrease in volume fraction between 766 and $927{ }^{\circ} \mathrm{C}$, completely disappearing by $1150{ }^{\circ} \mathrm{C}$. The larger pores do not show similar changes until above $1100{ }^{\circ} \mathrm{C}$. These results indicate that the nanoparticles begin sintering below $927^{\circ} \mathrm{C}$, and must be mostly responsible for the physical stability of the scaffolds calcined at $1000{ }^{\circ} \mathrm{C}$.

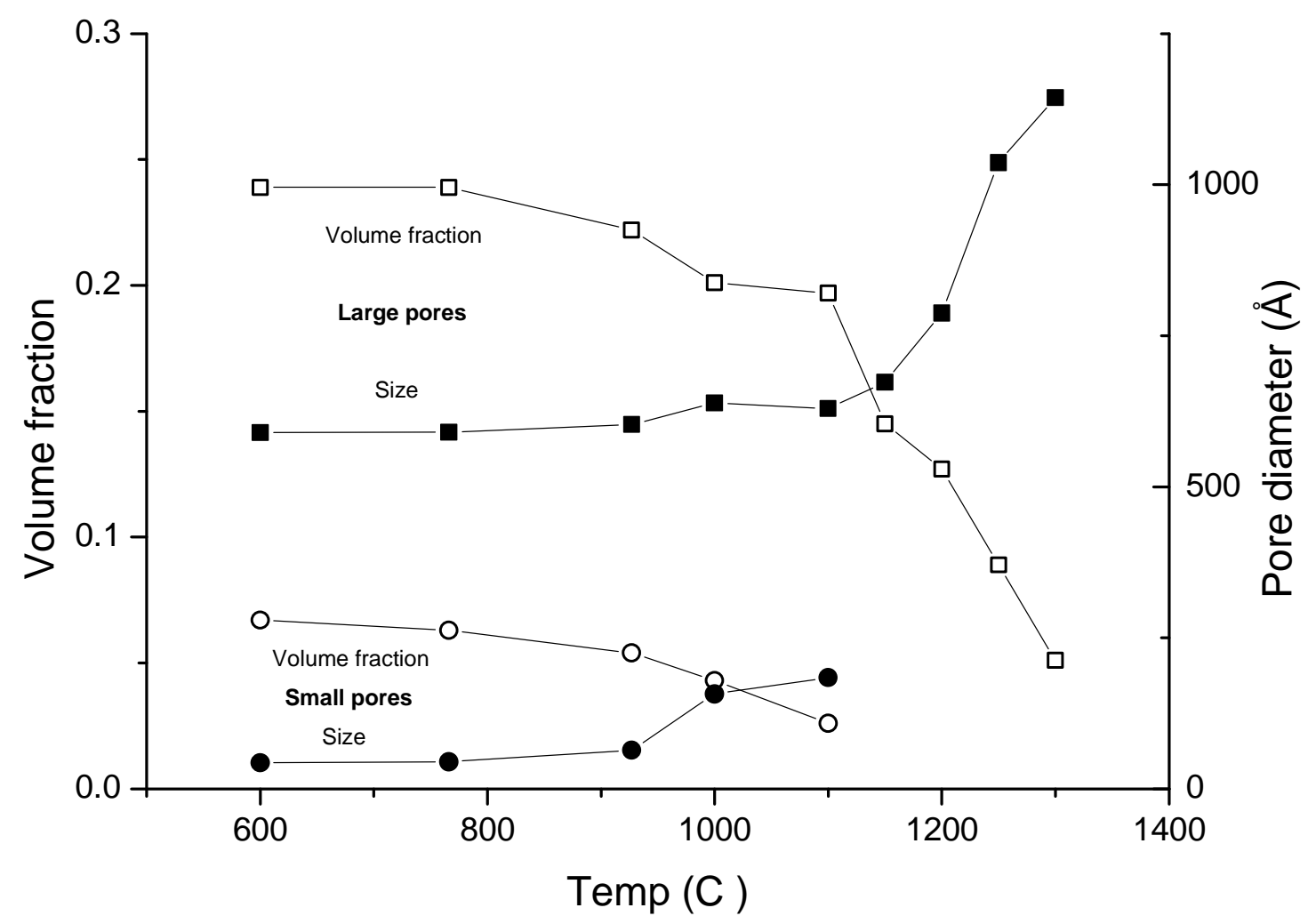

Figure 2. Pore size and volume against temperature derived from in situ USAXS data.

The final step in the fabrication of the anodes is impregnation of nickel nitrate solution, which is converted to nickel oxide on exposure to air. Because of the difference in density between the nickel nitrate solution and solid nickel oxide, the scaffolds need to be impregnated multiple times to obtain a percolating coverage of nickel oxide(18). In all cases the theoretical mass of impregnated nickel oxide was close to the measured mass. Because the volume of nickel nitrate solution added was determined empirically, from observation of whether or not the previous impregnation was fully absorbed, the nickel oxide loading is not identical between cells. The loading of nickel oxide is lower in multilayered cells, probably due to the reduced ability of the nickel nitrate solution to fully absorb into the deeper scaffolds.

Impregnated symmetrical cells were tested using impedance spectroscopy in order to assess the effects of scaffold calcination temperature and thickness of scaffold. Three cells heat-treated at $1000{ }^{\circ} \mathrm{C}$ were tested: single layer, double layer and triple layer. These were compared to a single layer cell produced using the same ink but calcined at $1300{ }^{\circ} \mathrm{C}$ in order to assess the differences between the scaffolds calcined at different temperatures. 
Figure 3 shows the impedance spectrum at $500{ }^{\circ} \mathrm{C}$ for the single layer cells as an example. All four cells show the two semi-circles typical of Ni-CGO anodes, with the high frequency response normally assigned to charge transfer processes and the low frequency response is normally assigned to diffusion processes. Modelling these cells as equivalent circuits (inset of figure 3) shows that in this case, the assignments are consistent with this, as the high frequency response decreases in size exponentially with increasing temperature as expected from a thermally-activated charge transfer process, while the lower frequency response decreases in size with increasing hydrogen concentration, as expected from a diffusion-based process. For the low frequency response, the changes with hydrogen concentration are much less pronounced for the cells heat-treated at $1000{ }^{\circ} \mathrm{C}$.

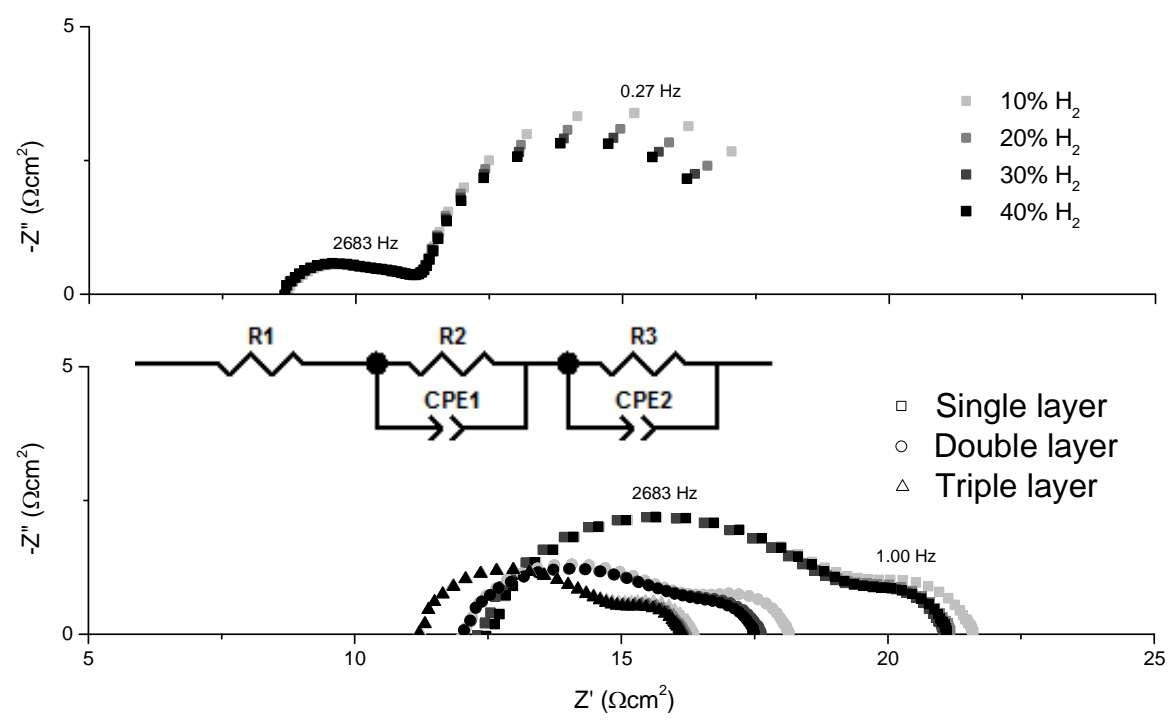

Figure 3. Impedance spectra for symmetrical cells tested at $500{ }^{\circ} \mathrm{C}$ produced from scaffolds heat-treated at $1300{ }^{\circ} \mathrm{C}$ (top) and $1000{ }^{\circ} \mathrm{C}$ (bottom). The characteristic frequencies of each response are displayed on the plot for the $10 \% \mathrm{H}_{2}$ single layer samples only. The inset shows the equivalent circuit used for modelling.

By examining the higher frequency response the authors have assigned as related to charge transfer, some differences between the anodes could be observed. For the cells with scaffolds heat-treated at $1000{ }^{\circ} \mathrm{C}$, the activation energy decreased as the number of layers increased, from $120 \mathrm{kJmol}^{-1}$ for one layer, $111 \mathrm{kJmol}^{-1}$ for two layers and 97.4 $\mathrm{kJmol}^{-1}$ for three. For the sample with a scaffold heat-treated at $1300{ }^{\circ} \mathrm{C}$, the calculated activation energy of $128 \mathrm{kJmol}^{-1}$ was comparable to the single layered cell heat-treated at $1000{ }^{\circ} \mathrm{C}$.

The samples heat-treated at $1000{ }^{\circ} \mathrm{C}$ showed much smaller polarisation in the low frequency response than the sample heat-treated at $1300{ }^{\circ} \mathrm{C}$, which is was consistent with the higher level of porosity demonstrated by USAXS and SEM. The scaffolds heattreated at $1000{ }^{\circ} \mathrm{C}$ all possessed lower resistances for the electrode component of the resistance than the scaffold heat-treated at $1300{ }^{\circ} \mathrm{C}$. The ohmic component of the resistance (the intercept with the $\mathrm{x}$-axis at the high frequency end) was larger by up to $50 \%$ in all the samples heat-treated at $1000{ }^{\circ} \mathrm{C}$, which suggests that the electrical contacts were poorer. Previous work on infiltrated electrodes using FIB-SEM 
tomography(18) has shown that the level of percolation of nickel is sensitive to the loading of nickel, it may be that the higher porosity of the lower temperature samples results in a poorer connectivity of nickel at the loadings used in these samples. The electrode resistances decrease with increasing number of layers, indicating that the active electrochemical volume was increasing in size.

Fuel cells were fabricated from the two layer scaffolds. Despite the slightly better performance noted in the triple-layered symmetrical cells, these were not produced due to the increased complexity of printing the extra layer. The measured power densities in $50 \% \mathrm{H}_{2}$ (Figure 4) showed that the cell produced using a scaffold heat-treated at $1300{ }^{\circ} \mathrm{C}$ outperformed the cell produced using a scaffolds heat-treated at $1000{ }^{\circ} \mathrm{C}$ (when tested at $800{ }^{\circ} \mathrm{C}$ ). However, at lower testing temperatures, the cell made from a scaffold heattreated at $1000{ }^{\circ} \mathrm{C}$ produced higher power densities. This is due to the difference in activation energy producing a different response to changing temperature.

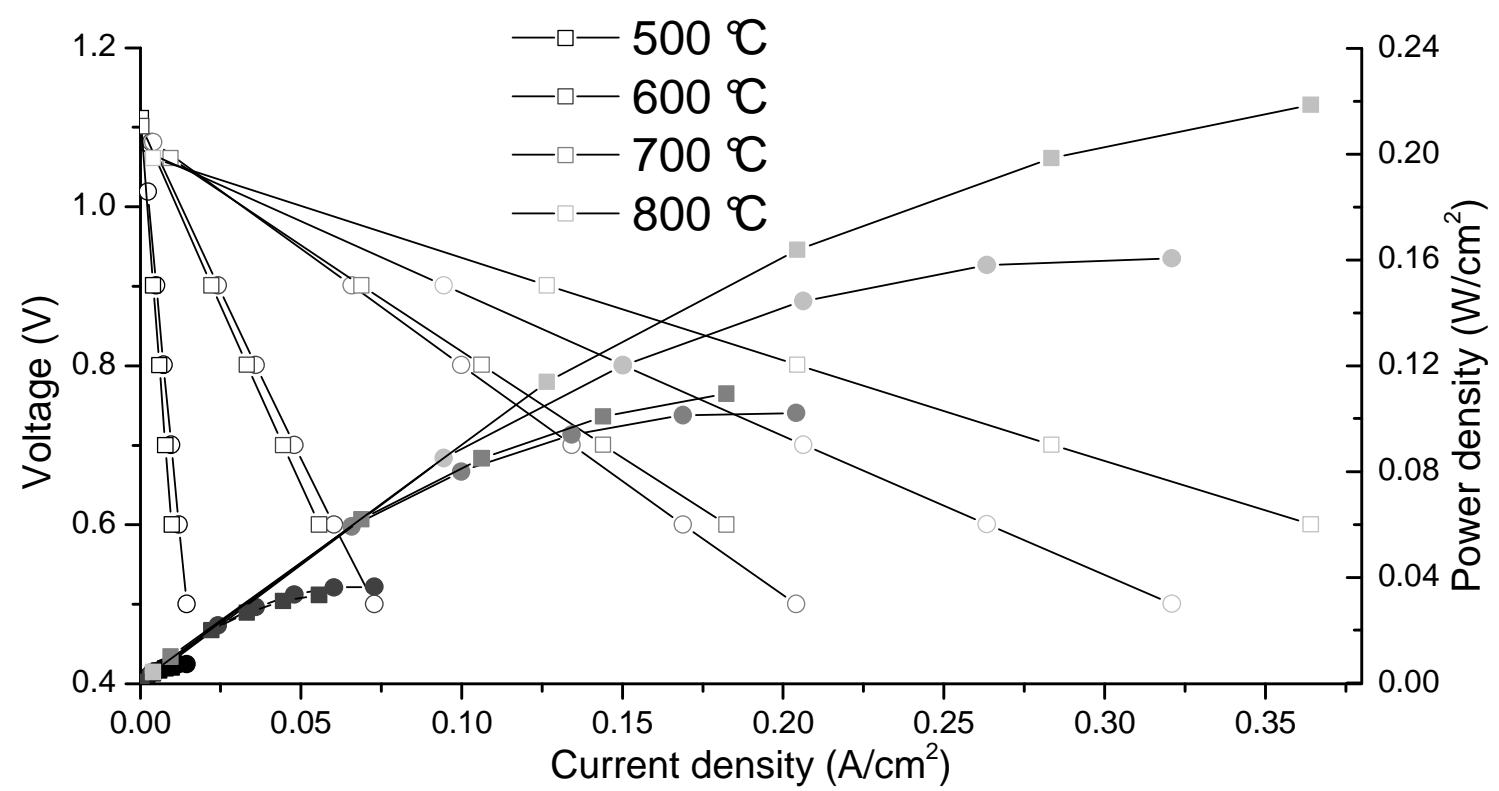

Figure 4. Power density curves measured under $50 \% \mathrm{H}_{2}$ for double layered scaffolds showing the effects of scaffold heat-treatment temperature. Scaffolds heat-treated at $1000{ }^{\circ} \mathrm{C}$ are circles while those heat-treated at $1300{ }^{\circ} \mathrm{C}$ are squares. Power densities are closed symbols, while voltages are open symbols.

These two cells were also tested in syngas (figure 5). In order to avoid exposing the cells to syngas at under conditions of low oxygen flux which may lead to carbon deposition, the cells were held at $0.5 \mathrm{~V}$ under $50 \% \mathrm{H}_{2}$ before switching to syngas and subsequently testing at $0.5-0.8 \mathrm{~V}$. In these tests, the cell produced from the scaffold heat-treated at $1000{ }^{\circ} \mathrm{C}$ performed better under all conditions. The energy content of the syngas fuel used is around $80 \%$ of the energy content of the $50 \% \mathrm{H}_{2}$ fuel used in the previous test. While the cell produced from the scaffold heat-treated at $1300{ }^{\circ} \mathrm{C}$ indeed shows $80 \%$ of the power density comparing the syngas test to the hydrogen test, the cell produced from the scaffold heat-treated at $1000{ }^{\circ} \mathrm{C}$ produces a higher relative power density than this. This suggests that this cell is more efficient under syngas than under hydrogen. 


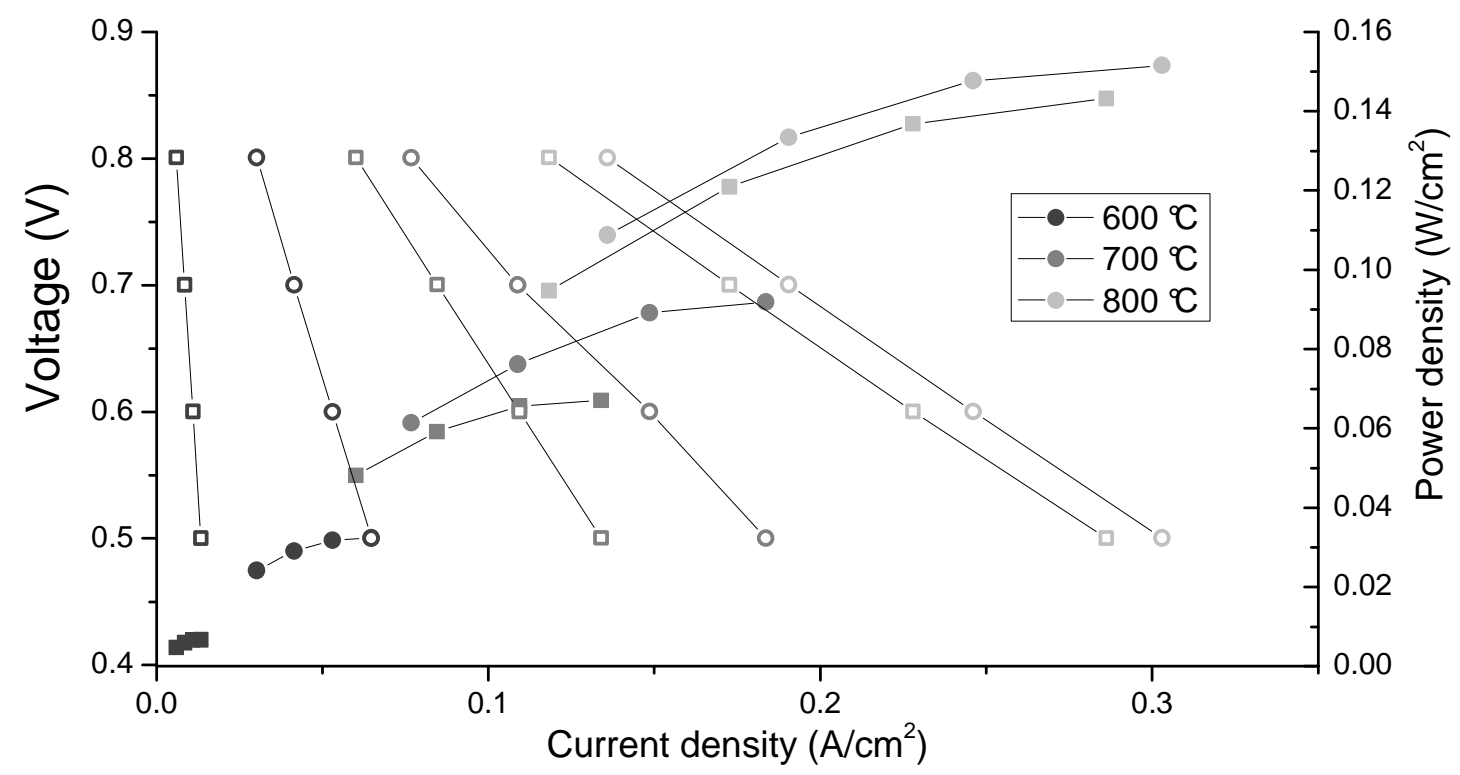

Figure 5. Fuel cell tests under humidified $15 \% \mathrm{H}_{2}, 25 \% \mathrm{CO}$ syngas showing the effect of scaffold sintering temperature. The scaffold heat-treated at $1000^{\circ} \mathrm{C}$ is in circles while the one heat-treated at $1300{ }^{\circ} \mathrm{C}$ is squares. Power densities are filled symbols while voltages are open symbols.

\section{Conclusions}

A strategy for incorporating nanoparticles into solid oxide fuel cell anodes has been demonstrated, and has been shown to confer benefits including lower onset of sintering temperatures, higher porosity and ultimately better performance at lower temperatures and under syngas. The nanoparticles used along with conventional micron-sized CGO particles appeared to act as a glue to enable the lower sintering temperatures. Low temperature routes towards solid oxide fuel cells should allow the use of more advanced catalysts, finer microstructure and materials which are not stable at higher temperatures.

\section{Acknowledgments}

PB would like to thank the H2FCSUPERGEN program for funding. ERT would like to thank funding provided by the EPSRC Advancing Biogas Utilization through Fuel Flexible SOFC project [EP/I037016/1]. EPSRC is also thanked for funding the pilot plant and confined jet mixer development [EP/E040551/1]. KCC would like to thank the U.S. Department of Energy (DOE), Solid State Energy Conversion Alliance (SECA). ChemMatCARS Sector 15 is principally supported by the National Science Foundation/DOE under grant number NSF/CHE-0822838. Use of the Advanced Photon Source was supported by the DOE, Office of Science, Office of Basic Energy Sciences, under Contract No. DE-AC02-06CH11357.

\section{References}

1. J.-Y. Kim, N. A. Kotov, Chemistry of Materials, 26(1), 134-152 (2013).

2. M. R. Somalu, N. P. Brandon, Journal of the American Ceramic Society, 95(4), 1220-1228, (2012). 
3. M. R. Somalu, V. Yufit, N. P. Brandon, International Journal of Hydrogen Energy, 38(22), 9500-9510 (2013).

4. 12 M. R. Somalu, A. Muchtar, M. G. Baboli, V. Yufit, I. P. Shapiro, P. Xiao, N. P. Brandon, Solid Oxide Fuel Cells 13 (Sofc-Xiii), 57(1), 1321-1330 (2013).

5. 13 M. R. Somalu, V. Yufit, I. P. Shapiro, P. Xiao, N. P. Brandon, International Journal of Hydrogen Energy, 38(16), 6789-6801 (2013).

6. K. Jono, S. Suda, M. Hattori, in Solid Oxide Fuel Cells 10, K. Eguchi, S. C. Singhai, H. Yokokawa, H. Mizusaki, H., Editors, Vol. 7, pp 1541-1546 (2007).

7. M. J. Lee, J. H. Jung, K. Zhao, B. H. Kim, Q. Xu, B. G. Ahn, S. S. H. Kim, S. Y. Kim, Journal of the European Ceramic Society, 34(7), 1771-1776 (2014).

8. C. J. Tighe, R. Q. Cabrera, R. I. Gruar, J. A. Darr, Industrial \& Engineering Chemistry Research, 52(16), 5522-5528 (2013).

9. E. Ruiz-Trejo, P. Boldrin, A. Lubin, F. Tariq, S. Fearn, R. Chater, S. N. Cook, A. Atkinson, R. I. Gruar, C. J. Tighe, J. Darr, N. P. Brandon, Chemistry of Materials, 26(13), 3887-3895 (2014).

10. A. Cabanas, J. A. Darr, E. Lester, M. Poliakoff, Chemical Communications, (11), 901-902 (2000).

11. A. Cabanas, J. A. Darr, E. Lester, M. Poliakoff, Journal of Materials Chemistry, 11(2), 561-568 (2001).

12. X. Weng, J. K. Cockcroft, G. Hyett, M. Vickers, P. Boldrin, C. C. Tang, S. P. Thompson, J. E. Parker, J. C. Knowles, I. Rehman, I. Parkin, J. R. G. Evans, J. A. Darr, Journal of Combinatorial Chemistry, 11(5), 829-834 (2009).

13. P. Boldrin, A. K. Hebb, A. A. Chaudhry, L. Otley, B. Thiebaut, P. Bishop, J. A. Darr, Industrial \& Engineering Chemistry Research, 46(14), 4830-4838 (2007).

14. X. Weng, P. Boldrin, I. Abrahams, S. J. Skinner, S. Kellici, J. A. Darr, Journal of Solid State Chemistry, 181(5), 1123-1132 (2008).

15. A. A. Chaudhry, S. Haque, S. Kellici, P. Boldrin, I. Rehman, F. A. Khalid, J. A. Darr, Chemical Communications, (21), 2286-2288 (2006).

16. R. I. Gruar, C. J. Tighe, J. A. Darr, Industrial \& Engineering Chemistry Research, 52(15), 5270-5281 (2013).

17. P. Fuoss, K. C. Chang, H. You, Journal of Electron Spectroscopy and Related Phenomena, 190, 75-83 (2013).

18. M. Kishimoto, M. Lomberg, E. Ruiz-Trejo, N. P. Brandon, Journal of Power Sources, 266, 291-295 (2014). 